Pacific Journal of Mathematics

AN INEQUALITY FOR THE DENSITY OF THE SUM OF SETS
OF VECTORS IN $n$-DIMENSIONAL SPAE 


\title{
AN INEQUALITY FOR THE DENSITY OF THE SUM OF SETS OF VECTORS IN $n$-DIMENSIONAL SPACE
}

\author{
Allen R. Freedman
}

\begin{abstract}
A Schnirelmann type density is defined for sets of "nonnegative" lattice points. If $A, B$ and $C=A+B$ are such sets with densities $\alpha, \beta$ and $\gamma$ respectively, then it is shown that $\gamma \geqq \beta /(1-\alpha)$ provided $\alpha+\beta<1$.
\end{abstract}

1. Let $n$ be a positive integer and let $Q$ be the set of all vectors $r=\left(\rho_{1}, \cdots, \rho_{n}\right)$ where each $\rho_{i}$ is a nonnegative integer and at least one $\rho_{i}$ is positive. We define a partial order relation $<$ on $Q$ where $r<s$ if and only if $\rho_{i} \leqq \sigma_{i}(i=1,2, \cdots, n)$ with strict inequality holding for at least one index. Denote by $L(r)$ the set of all $x$ in $Q$ for which either $x<r$ or $x=r$.

A nonempty finite subset $F$ of $Q$ is called fundamental if, whenever $r \in F$, then $L(r) \leqq F$. For $A, X \subseteq Q$ with $X$ finite, let $A(X)$ denote the number of vectors in $A \cap X$. Then the (Kvarda) density of $A$ is

$$
\alpha=\operatorname{glb} \frac{A(F)}{Q(F)}
$$

where $F$ ranges over all fundamental subsets of $Q$.

Let $B \subseteq Q$ and define $A+B=\{a, b, a+b \mid a \in A, b \in B\}$ where addition of vectors is done coordinatewise. Let $\beta$ and $\gamma$ be the densities of $B$ and $C=A+B$ respectively. Kvarda [1] has proved the inequaliy $\gamma=\alpha+\beta-\alpha \beta$ which for $n=1$ was first proved by Landau and Schnirelmann. In this paper we prove $\gamma \geqq \beta /(1-\alpha)$ provided $\alpha+\beta<1$. For $n=1$, this has been proved by Schur [2].

\section{Main results.}

Lemma 1. Let $\bar{C}$ denote the complement of $C$ in $Q$ and suppose $\bar{C} \neq \Phi . \quad F o r$ a fundamental set $F$ let $F^{*}$ denote the set of maximal vectors of $F$ with respect to the partial ordering <. Then

$$
\gamma=\operatorname{glb} \frac{C(F)}{Q(F)}
$$

where $F$ ranges over all fundamental sets with $F^{*} \cong \bar{C}$.

Proof. Let $\gamma^{\prime}$ denote this glb. Clearly $\gamma \leqq \gamma^{\prime}$. Let $G$ be any fundamental set. If $C(G)=Q(G)$ then $C(G) / Q(G)=1>\gamma^{\prime}$. If $C(G)<Q(G)$ then $\bar{C} \cap G \neq \Phi$. In this case let $F$ be the union of all 
sets $L(g)$ where $g \in \bar{C} \cap G$. Evidently $F$ is a fundamental set, $F \cong G$, and $F^{*} \subseteq \bar{C}$. Thus,

$$
\frac{C(G)}{Q(G)}=\frac{C(F)+C(G-F)}{Q(F)+Q(G-F)}=\frac{C(F)+Q(G-F)}{Q\left(F^{\prime}\right)+Q(G-F)} \geqq \frac{C(F)}{Q(F)} \geqq \gamma^{\prime},
$$

and so $\gamma \geqq \gamma^{\prime}$.

LEMma 2. If $F$ is a fundamental set with $F^{*} \cong \bar{C}$, then $C(F) \geqq \alpha C(F)+B(F)$.

Proof. Let $g_{1}, g_{2}, \cdots, g_{k}$ be the vectors of $\bar{C} \cap F$, indexed in such a way that

$$
g_{i}<g_{j} \text { implies } i<j \text {. }
$$

Define $H_{1}=L\left(g_{1}\right)$ and $H_{i+1}=L\left(g_{i+1}\right)-\bigcup_{j=1}^{i} H_{j}$. Then

(2) the $H_{i}$ are disjoint,

(3) the union of the $H_{i}$ is $F$, and

(4) for each $i, g_{i} \in H_{i}$.

Now (2) follows immediately by definition, and (3) from the fact that since $F^{*} \subseteq \bar{C}$, we have for each $x \in F$, that $x \in L\left(g_{i}\right)$ for some $i$. To prove (4) notice that $g_{i} \notin H_{i}$ implies $g_{i} \in \bigcup_{j=1}^{i-1} H_{j}$, which in turn implies $g_{i} \in L\left(g_{j_{0}}\right)$ for some $j_{0}<i$, contrary to (1).

For each $i$ let $t H_{i}$ be the set of all vectors $g_{i}-x$ where $x$ ranges over $H_{i}-\left\{g_{i}\right\}_{\text {. Then }}$

(5) $t H_{i}$ is either empty or is a fundamental set, and

(6) $Q\left(t H_{i}\right)=Q\left(H_{i}\right)-1$.

To show (5) let $z$ be an arbitrary vector in $t H_{i}$ and let $y \in L(z)$. We have $g_{i}-z \leqq g_{i}-y<g_{i}$. Thus $g_{i}-y \in L\left(g_{i}\right)-\left\{g_{i}\right\}$ and, since $g_{i}-z \in H_{i}$, we have $g_{i}-y \in H_{i}-\left\{g_{i}\right\}$. Hence $g_{i}-\left(g_{i}-y\right)=y \in t H_{i}$ and so $L(z) \subseteq t H_{i}$. Equation (6) is immediate.

Now, for each $\alpha \in A \cap t H_{i}$, there exists a unique $x \in H_{i}-\left\{g_{i}\right\}$ such that $a=g_{i}-x$. Thus $x \in \bar{B}$. Also, by (4), we have $g_{i} \in \bar{B} \cap H_{i}$ and so

$$
\begin{aligned}
\bar{B}\left(H_{i}\right) & \geqq A\left(t H_{i}\right)+1 \\
& \geqq \alpha Q\left(t H_{i}\right)+1 \quad(\text { from }(5) \text { and the definition of } \alpha) \\
& =\alpha\left(Q\left(H_{i}\right)-1\right)+1 \quad(\text { from }(6)) .
\end{aligned}
$$

Summing over $i$, using (2) and (3), we obtain

$$
\begin{aligned}
\bar{B}(F) & \geqq \alpha(Q(F)-k)+k \\
& =\alpha C(F)+\bar{C}\left(F^{\prime}\right)
\end{aligned}
$$

that is, 


$$
C(F) \geqq \alpha C(F)+B(F)
$$

Theorem. If $\alpha+\beta<1$ then $\gamma \geqq \beta /(1-\alpha)$.

Proof. Since $\beta<1-\alpha$ and $\alpha<1$, then $\beta /(1-\alpha)<1$. Hence if $\gamma=1$, the theorem follows. If $\gamma<1$, then $\bar{C} \neq \Phi$ and for any fundamental set $F$ with $F^{*} \subseteq \bar{C}$ we have by Lemma 2

$$
C(F) \geqq \alpha C(F)+B(F) \text {. }
$$

Hence,

$$
\frac{C(F)}{Q(F)} \geqq \alpha \frac{C(F)}{Q(F)}+\frac{B(F)}{Q(F)} \geqq \alpha \gamma+\beta .
$$

By Lemma $1 \gamma \geqq \alpha \gamma+\beta$ that is, $\gamma \geqq \beta /(1-\alpha)$.

3. Remark. A result of Kvarda [1] states that if $\alpha+\beta \geqq 1$ then $\gamma=1$. This result and the above theorem can be used to prove quickly that if $\alpha>0$ then $A$ is a basis for $Q$, that is, $n A=Q$ for some $n$, where $i A=(i-1) A+A$ for $i \geqq 2$. Thus let $\gamma_{i}$ denote the density of $i A$ and assume that $n A \neq Q$ for all $n$. Then, for all $k, \gamma_{k}+\alpha<1$, and so

$$
\gamma_{k+1} \geqq \frac{\gamma_{k}}{1-\alpha} \geqq \frac{\gamma_{k-1}}{(1-\alpha)^{2}} \geqq \cdots \geqq \frac{\gamma_{1}}{(1-\alpha)^{k}}=\frac{\alpha}{(1-\alpha)^{k}}
$$

But, for $k$ sufficiently large, $\left(\alpha /(1-\alpha)^{k}\right) \geqq 1$, a contradiction.

\section{REFERENCES}

1. B. Kvarda, On densities of sets of lattice points, Pacific J. Math. 13 (1963), 611-615. 2. I. Schur, Über den Begriff der Dichte in der additiven Zahlentheorie, S. B. Preuss. Akad. Wiss. Phys. Math. Kl. (1936), 269-297.

Received June 12, 1965. This paper is part of the author's Ph. D. thesis, written at Oregon State University under the direction of Professor Robert Stalley. 



\title{
PACIFIC JOURNAL OF MATHEMATICS
}

\author{
EDITORS
}

\section{H. SAMELSON}

Stanford University

Stanford, California

J. P. JANS

University of Washington

Seattle, Washington 98105
J. DugundJI

University of Southern California

Los Angeles, California 90007

RICHARD ARENS

University of California

Los Angeles, California 90024

\section{ASSOCIATE EDITORS}

\section{E. F. BECKENBACH}

B. H. NEUMANN

F. WOLF

K. YosidA

\section{SUPPORTING INSTITUTIONS}

\author{
UNIVERSITY OF BRITISH COLUMBIA \\ CALIFORNIA INSTITUTE OF TECHNOLOGY \\ UNIVERSITY OF CALIFORNIA \\ MONTANA STATE UNIVERSITY \\ UNIVERSITY OF NEVADA \\ NEW MEXICO STATE UNIVERSITY \\ OREGON STATE UNIVERSITY \\ UNIVERSITY OF OREGON \\ OSAKA UNIVERSITY \\ UNIVERSITY OF SOUTHERN CALIFORNIA
}

\author{
STANFORD UNIVERSITY \\ UNIVERSITY OF TOKYO \\ UNIVERSITY OF UTAH \\ WASHINGTON STATE UNIVERSITY \\ UNIVERSITY OF WASHINGTON \\ AMERICAN MATHEMATICAL SOCIETY \\ CHEVRON RESEARCH CORPORATION \\ TRW SYSTEMS \\ NAVAL ORDNANCE TEST STATION
}

Mathematical papers intended for publication in the Pacific Journal of Mathematics should be typewritten (double spaced). The first paragraph or two must be capable of being used separately as a synopsis of the entire paper. It should not contain references to the bibliography. Manuscripts may be sent to any one of the four editors. All other communications to the editors should be addressed to the managing editor, Richard Arens at the University of California, Los Angeles, California 90024.

50 reprints per author of each article are furnished free of charge; additional copies may be obtained at cost in multiples of 50 .

The Pacific Journal of Mathematics is published monthly. Effective with Volume 16 the price per volume (3 numbers) is $\$ 8.00$; single issues, $\$ 3.00$. Special price for current issues to individual faculty members of supporting institutions and to individual members of the American Mathematical Society: $\$ 4.00$ per volume; single issues $\$ 1.50$. Back numbers are available.

Subscriptions, orders for back numbers, and changes of address should be sent to Pacific Journal of Mathematics, 103 Highland Boulevard, Berkeley 8, California.

Printed at Kokusai Bunken Insatsusha (International Academic Printing Co., Ltd.), No. 6, 2-chome, Fujimi-cho, Chiyoda-ku, Tokyo, Japan.

PUBLISHED BY PACIFIC JOURNAL OF MATHEMATICS, A NON-PROFIT CORPORATION

The Supporting Institutions listed above contribute to the cost of publication of this Journal, but they are not owners or publishers and have no responsibility for its content or policies. 


\section{Pacific Journal of Mathematics \\ Vol. 19, No. $2 \quad$ June, 1966}

Leonard Daniel Baumert, Extreme copositive quadratic forms . ......... 197

Fred James Bellar, Jr., Pointwise bounds for the second initial-boundary value problem of parabolic type ........................ 205

L. Carlitz and David Paul Roselle, Restricted bipartite partitions ........ 221

Robin Ward Chaney, On the transformation of integrals in measure space ........................................... 229

Colin W. Clark, An embedding theorem for function spaces ........... 243

Edwin Duda, A theorem on one-to-one mappings................ 253

Ben Fitzpatrick, Jr. and Donald Reginald Traylor, Two theorems on metrizability of Moore spaces.......................... 259

Allen Roy Freedman, An inequality for the density of the sum of sets of vectors in $n$-dimensional space ....................... 265

Michael Friedberg, On representations of certain semigroups .......... 269

Robert William Gilmer, Jr., The pseudo-radical of a commutative ring . . . . 275

Hikosaburo Komatsu, Fractional powers of operators ............... 285

Daniel Rider, Transformations of Fourier coefficients ................. 347

David Alan Sánchez, Some existence theorems in the calculus of variations ...................................... 357

Howard Joseph Wilcox, Pseudocompact groups............... 365

William P. Ziemer, Some lower bounds for Lebesgue area ............. 381 